\title{
Kinetic Study of Styrene Oxidation over Titania Catalyst Supported on Sulfonated Fish Bone-derived Carbon
}

\author{
Ratna Kusumawardani ${ }^{1}$, Mukhamad Nurhadi1,*, Teguh Wirawan ${ }^{2}$, Anton Prasetyo ${ }^{3}$, \\ Nabila Nur Agusti ${ }^{3}$, Sin Yuan Lai ${ }^{4,5}$, Hadi Nur ${ }^{6,7}$
}

${ }^{1}$ Department of Chemical Education, Universitas Mulawarman, Kampus Gunung Kelua, Samarinda, 75119, East Kalimantan, Indonesia.

${ }^{2}$ Chemistry Department, Universitas Mulawarman, Kampus Gunung Kelua, Samarinda, 75119, East Kalimantan, Indonesia.

${ }^{3}$ Chemistry Department, Faculty Science and Technology, Universitas Islam Negeri Maulana Malik Ibrahim Malang, Jalan Gajayana 50 Malang, 65144, Indonesia.

${ }^{4}$ School of Energy and Chemical Engineering, Xiamen University Malaysia, Selangor Darul Ehsan 43900, Malaysia.

${ }^{5}$ College of Chemistry and Chemical Engineering, Xiamen University, Xiamen 361005, China.

${ }^{6}$ Department of Chemistry, Universitas Negeri Malang, Malang 65145, Indonesia.

${ }^{7}$ Center of Advanced Materials for Renewable Energy (CAMRY), Universitas Negeri Malang, Jl. Semarang No. 5, Malang 65145, Indonesia.

Received: 10 ${ }^{\text {th }}$ December 2021; Revised: 22 $2^{\text {nd }}$ January 2022; Accepted: $24^{\text {th }}$ January 2022

Available online: 31 st January 2022; Published regularly: March 2022

\section{Abstract}

The kinetic evaluation of titania supported sulfonated fish bone-derived carbon ( $\mathrm{TiO}_{2} / \mathrm{SFBC}$ ) as a catalyst in styrene oxidation by aqueous hydrogen peroxide was carried out. The catalysts were prepared by carbonation of fishbone powder at varying temperatures 500,600 and $700{ }^{\circ} \mathrm{C}$, respectively for $2 \mathrm{~h}$, followed by sulfonation with sulfuric acid (1M) for $24 \mathrm{~h}$ and impregnated by varied titania concentration 500, 1000 and $1500 \mu$ mol. The physical properties of catalysts were characterized using Fourier transform infrared (FTIR) spectroscopy, X-ray diffraction (XRD), Scanning Electron Microscope-Energy Dispersive X-Ray (SEM-EDX) and the nitrogen adsorptiondesorption analysis. The catalytic activity result showed that $\mathrm{TiO}_{2} / \mathrm{SFBC}$ can be used as a potential catalyst in styrene oxidation. Worth noting that the sulfonation process has not only transformed the $\mathrm{TiO}_{2} / \mathrm{FBC}$ particulates (without sulfonation) to cuboid-shaped $\mathrm{TiO}_{2} / \mathrm{SFBC}$ (with sulfonation) but also contributed to the high selectivity of benzaldehyde. On the other hand, carbonization at different temperatures has an indistinct effect on catalytic performance due to their similar surface areas. The styrene conversion rate responded positively with the increasing amount of titania in the functionalized composites. The styrene oxidation by aqueous $\mathrm{H}_{2} \mathrm{O}_{2}$ unraveled the firstorder reaction with the activation energy of $\sim 63.5 \mathrm{~kJ}$.

Copyright (C) 2022 by Authors, Published by BCREC Group. This is an open access article under the CC BY-SA License (https://creativecommons.org/licenses/by-sa/4.0).

Keywords: Styrene oxidation; titania; fishbone-derived carbon; carbonization; sulfonation

How to Cite: R. Kusumawardani, M. Nurhadi, T. Wirawan, A. Prasetyo, N.N. Agusti, S.Y. Lai, H. Nur (2022). Kinetic Study of Styrene Oxidation over Titania Catalyst Supported on Sulfonated Fish Bone-derived Carbon. Bulletin of Chemical Reaction Engineering \& Catalysis, 17(1), 194-204 (doi: 10.9767/bcrec.17.1.13133.194-204)

Permalink/DOI: https://doi.org/10.9767/bcrec.17.1.13133.194-204

\section{Introduction}

In academic research and industrial fine chemicals synthesis, styrene oxidation is an in-

\footnotetext{
* Corresponding Author.

Email: nurhadi1969@yahoo.co.id (M. Nurhadi);

Telp.: +62 81346482251; Fax: +62 541743929
}

dispensable reaction because of its commercialized products, including styrene oxide, benzaldehyde or phenylacetaldehyde. Benzaldehyde is the main product of styrene oxidation that is widely manufactured in many commercial products, such as perfume materials, anthelmintics, 
epoxy resins, plasticizers, drugs, sweeteners, chiral pharmaceuticals, pesticides, and epoxy paints [1-3]. Due to these commercial commodities, innumerable researchers have taken vast efforts to find catalysts that could increase the product yield of benzaldehyde resulted from styrene oxidation. One of the extensively used catalysts is titania-based catalysts [4-7].

Titanium dioxide $\left(\mathrm{TiO}_{2}\right)$ or titania is a very well-researched material that exhibits high efficiency in the oxidation reaction due to its structural stability, biocompatibility, optical and electrical properties. In nature, titania can be found in four polymorphs of minerals form such as rutile, anatase, and brookite and titanium dioxide (B) or $\mathrm{TiO}_{2}$ (B) [7,8]. Anatase and rutile are commonly used in the oxidation reaction due to commercial availability, large amounts of reactive oxygen species like hydroxyl $(\cdot \mathrm{OH})$ radicals, hydroperoxy radicals $(\cdot \mathrm{OOH})$ and superoxide $\left(\cdot \mathrm{O}_{2}^{-}\right)$radical anion onto $\mathrm{TiO}_{2}$ surface [9]. However, styrene oxidation using titania could only give low product yields if it is used without any catalyst supports $[10,11]$.

Fabrication titania by impregnation onto a variety of supports has been investigated in styrene oxidation. These catalysts are carboncoated titania [12,13], Coal char-loaded $\mathrm{TiO}_{2}$ [10], Coal char-loaded $\mathrm{TiO}_{2}$ by sulfonation and alkylsilylation [11], TS-1 zeolite [14], Ti-MCM41 [15], Ti-LHMS-3 [16], V-Ti-MCM-41 and NbTi-MCM-4 [17], Titanium Dioxide-Supported Sulfonated Low Rank Coal [18]. Despite being high catalytic activity and selectivity, these catalysts customarily involve complicated preparation method and economically infeasible for extensive applications.

Indonesia is the largest archipelagic country in the world with a sea area of 5.8 million $\mathrm{km}^{2}$ [19] and the largest fishery potential in the world with a potential of 67 million tons/year [20]. In 2014, Indonesia was the second-largest producer of aquaculture in the world, just ranked behind China [21]. Regardless of the fisheries and aquacultures have vastly developed, the large production of fish waste could cause the environmental issue. By taking this into consideration, valorization of fish waste into value-added commodities, such as bioactive peptides, collagen, enzymes, chitosan, and so forth, has been advocated [22]. In recent years, fish waste has been used as catalysts in biodiesel production [23-25].

Prompted by simple preparation methods and cost-effective raw materials, our research team first adopted facile impregnation synthesis using carbonized fishbone waste as the sup- port for metals $\left(\mathrm{Fe}_{2} \mathrm{O}_{3} / \mathrm{CFB}, \mathrm{CuO} / \mathrm{CFB}\right.$, and $\mathrm{TiO}_{2} / \mathrm{CFB}, \mathrm{CFB}=$ carbon-derived fish bone) in styrene oxidation [4]. In this research, we utilized a similar approach to synthesize the catalyst, whilst focusing more on the parameters, consisting of the temperature of carbonization, with and without the addition of $\mathrm{H}_{2} \mathrm{SO}_{4}$, and concentration of titania. In detail, the fishbone supports were prepared by carbonation for 2 hours at varying temperatures, 500, 600 and $700{ }^{\circ} \mathrm{C}$; Subsequently, sulfonation $\left(1 \mathrm{M} \mathrm{H}_{2} \mathrm{SO}_{4}\right)$ to the carbonized powder for $24 \mathrm{~h}$; Lastly, impregnation of titania (500, 1000 and 1500 $\mu \mathrm{mol})$ with fishbone-derived hydroxyapatite. The effects of carbonization, sulfonation and titania concentration were studied to understand the structure-properties relationships of the catalyst. Since a catalyst can open a new reaction pathway with lower activation energy, the kinetic performance of the catalysts was evaluated via styrene oxidation in the presence of an aqueous $\mathrm{H}_{2} \mathrm{O}_{2}$ oxidant.

\section{Materials and Methods}

\subsection{Carbonation Process}

Carbon-containing hydroxyapatite was prepared from the waste of fish bones that was collected from many food companies around Samarinda, East Kalimantan, Indonesia. The fish bone powder was carbonized in a furnace at varied temperatures $\left(500,600\right.$, and $700{ }^{\circ} \mathrm{C}$ ) for $2 \mathrm{~h}$ to form carbon. The fish bone-derived carbon is labeled as $\mathrm{FBC}(\mathrm{T})$, where $\mathrm{T}$ is the carbonation temperature. For example, FBC500 is the fish bone-derived carbon that is prepared via the carbonation process at $500{ }^{\circ} \mathrm{C}$ for $2 \mathrm{~h}$.

\subsection{Sulfonation Process}

The sulfonation process to the FBC500 was carried out by adding $10 \mathrm{~mL}$ of sulfuric acid (1 M; JT Beker) per gram of sample. The mixture was stirred at room temperature for $24 \mathrm{~h}$ and washed with distillate water to remove any loosely bound acid and it was dried at $110^{\circ} \mathrm{C}$ overnight. FBC500 which has sulfonated is indicated as sulfonated fish bone-derived carbon (SFBC500).

\subsection{Titania Impregnation}

The titania impregnation process was obtained from the previous research [4]. Every 1 gram carbon was impregnated by titanium(IV) isopropoxide (500 $\mu \mathrm{mol}$, Sigma Aldrich) that was immersed in $10 \mathrm{~mL}$ acetone (Merck) and stirred until all of the acetone solvents completely evaporated. The residual acetone was 
removed from the carbon sample by washing with ethanol (Merck) and subsequently dried at $110{ }^{\circ} \mathrm{C}$ overnight. The carbon sample was impregnated and labeled as $\mathrm{TiO}_{2}(\mathrm{x}) / \mathrm{FBC}(\mathrm{T}), \mathrm{x}=$ concentration of $\mathrm{TiO}_{2}$ and $\mathrm{T}=$ temperature of carbonization. For example, $\mathrm{TiO}_{2}(500) / \mathrm{FBC} 500$ was generated from fish bone-derived carbon that was prepared by carbonation process at $500{ }^{\circ} \mathrm{C}$ for $2 \mathrm{~h}$ and the resultant was impregnated by titanium(IV) isopropoxide $(500 \mu \mathrm{mol})$. The codes of all samples can be listed in Table 1.

\subsection{Samples Characterization}

A series of samples were characterized, including $\mathrm{TiO}_{2}\left(\begin{array}{ll}500 & 0\end{array}\right) / \mathrm{F} \mathrm{B} \mathrm{C} 500$, $\mathrm{TiO}_{2}(500) / \mathrm{SFBC} 500, \quad \mathrm{TiO}_{2}(500) / \mathrm{SFBC} 600$, $\mathrm{TiO}_{2}(500) / \mathrm{SFBC} 700, \mathrm{TiO}_{2}(1000) / \mathrm{SFBC} 500$ and $\mathrm{TiO}_{2}(1500) / \mathrm{SFBC} 500$, to investigate the structure-activity relationships between the catalysts and the styrene oxidation. The samples were characterized by using FTIR, XRD, SEMEDX and BET adsorption-desorption. FTIR spectrometer (IR-Prestige-21 Shimadzu) with a spectral resolution of $2 \mathrm{~cm}^{-1}$, scans $10 \mathrm{~s}$, at temperature $20{ }^{\circ} \mathrm{C}$ and range of wavenumber from 400 to $4000 \mathrm{~cm}^{-1}$ was used to identify the functional groups in the catalyst. The crystallinity and phase content of the catalyst was analyzed using XRD instrument (Phillips PANalytical X'Pert PRO) with the $\mathrm{Cu}-\mathrm{K}_{a}(\lambda=$ $1.5406 \AA$ ) radiation as the diffracted monochromatic beam at $40 \mathrm{kV}$ and $40 \mathrm{~mA}$ and the pattern was scanned in the $2 \theta$ ranges between $7^{\circ}$ and $60^{\circ}$ at a step $0.03^{\circ}$ and step time $1 \mathrm{~s}$. The SEM-EDX (FEI Inspect S50) instrument with an accelerating voltage of $15 \mathrm{kV}$ was used to determine the surface morphology and element containing the catalyst. The nitrogen adsorption-desorption isotherms were measured at bath temperature $77.3 \mathrm{~K}$ and outgas tempera- ture $300.0{ }^{\circ} \mathrm{C}$ using a Quantachrome NovaWIn instrument version 11.0.

\subsection{Catalytic Activity Test}

The catalysts were tested by styrene oxidation reaction with aqueous hydrogen peroxide $\left(\mathrm{H}_{2} \mathrm{O}_{2}\right)$ as an oxidant. The catalytic reactions procedure was conducted according to the previous research. All reactions were performed by mixing styrene (Merck; $5 \mathrm{mmol}$ ), 30\% aqueous $\mathrm{H}_{2} \mathrm{O}_{2}$ (Merck; $5 \mathrm{mmol}$ ), acetonitrile (Merck; 4.5 $\mathrm{mL}$ ), and catalyst $(100 \mathrm{mg}$ ) with stirring for 24 $\mathrm{h}$ at room temperature. The products were then separated from the catalysts by centrifugation. A portion of the resulting liquid mixture was withdrawn and analyzed by GC-2010 Shimadzu-gas chromatograph equipped with a SH-Rxi-5ms column (30 m x $0.25 \mathrm{mmID} \times 0.25$ $\mu \mathrm{m} \mathrm{df}$ ), serial 1652111, a flame ionization detector (FID) and nitrogen as the carrier gas. The temperatures of the injector and detector were programmed at 250 and $260{ }^{\circ} \mathrm{C}$, respectively. The temperature of the column oven was programmed to increase from 80 to $140{ }^{\circ} \mathrm{C}$, at a rate of $10{ }^{\circ} \mathrm{C} / \mathrm{min}$.

\section{Results and Discussion}

\subsection{Physical Properties}

The FTIR spectra of (a) FBC500, (b) SFBC500, (c) $\mathrm{TiO}_{2}(500) / \mathrm{FBC} 500, \quad$ (d) $\mathrm{TiO}_{2}(500) / \mathrm{SFBC} 500$, (e) $\mathrm{TiO}_{2}(500) / \mathrm{SFBC} 600$, (f) $\mathrm{TiO}_{2}(500) / \mathrm{SFBC} 700, \quad(\mathrm{~g}) \quad \mathrm{TiO}_{2}(1000) / \mathrm{SFBC} 500$ and (h) $\mathrm{TiO}_{2}(1500) / \mathrm{SFBC} 500$ were measured in 400-4000 $\mathrm{cm}^{-1}$ and are shown in Figure 1. All spectra show absorption peaks around $3200-3600 \mathrm{~cm}^{-1}$ and $1626 \mathrm{~cm}^{-1}$ are assigned the $\mathrm{O}-\mathrm{H}$ stretching which might be attributed to adsorbed water molecules. The absorption peaks at $2921 \mathrm{~cm}^{-1}$ were attributed to the symmetric and asymmetric stretching mode of the

Table 1. Codes and treatments done to the samples.

\begin{tabular}{lccccc}
\hline Samples & $\begin{array}{c}\text { Type of treat- } \\
\text { ment }\end{array}$ & $\begin{array}{c}\text { Time of } \\
\text { sulfonation } \\
(\mathrm{h})\end{array}$ & $\begin{array}{c}\text { Temperature } \\
\text { of carbonation } \\
\left({ }^{\circ} \mathrm{C}\right)\end{array}$ & $\begin{array}{c}\text { Time of } \\
\text { carbonation } \\
(\mathrm{h})\end{array}$ & $\begin{array}{c}\text { Titanium } \\
\text { impregnation } \\
(\mu \mathrm{mol})\end{array}$ \\
\hline No catalyst & - & - & - & - & - \\
$\mathrm{TiO}_{2}$ & - & - & - & - & - \\
$\mathrm{FBC500}_{\mathrm{SFBC500}}$ & - & - & 500 & 2 & - \\
$\mathrm{TiO}_{2}(500) /$ FBC500 & Sulfonation & 24 & 500 & 2 & - \\
$\mathrm{TiO}_{2}(500) /$ SFBC500 & Sulfonation & 24 & 500 & 2 & 500 \\
$\mathrm{TiO}_{2}(500) /$ SFBC600 & Sulfonation & 24 & 500 & 2 & 500 \\
$\mathrm{TiO}_{2}(500) /$ SFBC700 & Sulfonation & 24 & 600 & 2 & 500 \\
$\mathrm{TiO}_{2}(1000) /$ SFBC500 & Sulfonation & 24 & 700 & 2 & 500 \\
$\mathrm{TiO}_{2}(1500) /$ SFBC500 & Sulfonation & 24 & 500 & 2 & 1000 \\
\hline
\end{tabular}


aromatic and aliphatic $\mathrm{C}-\mathrm{H}$. The presence of hydroxyapatite in all samples was proven by the appearance of carbonate ion $\left(\mathrm{CO}_{3}{ }^{2-}\right)$ and phosphate ion $\left(\mathrm{PO}_{4}{ }^{3-}\right)$ groups [26-31]. The carbonate ion $\left(\mathrm{CO}_{3}{ }^{2-}\right)$ which comprised of $\mathrm{C}-\mathrm{O}$ stretching, showed the absorption band at around 1050-1300 $\mathrm{cm}^{-1}$ and $877 \mathrm{~cm}^{-1}$. The phosphate ion $\left(\mathrm{PO}_{4}^{3-}\right)$ groups that correlated with the $\mathrm{P}-\mathrm{O}$ stretching vibration was proven by the absorption bands at $1094 \mathrm{~cm}^{-1}$. The functional group resulted from the sulfonation process is illustrated in Figure $1(b, d-h)$ the absorption peaks exhibited at 1179 and 1030 $\mathrm{cm}^{-1}$. The absorption bands near $1179 \mathrm{~cm}^{-1}$ are due to symmetric vibrations of $\mathrm{S}-\mathrm{O}-\mathrm{Si}$ bridges [32]. The absorption peak near $1030 \mathrm{~cm}^{-1}$ represents $\mathrm{S}=\mathrm{O}$ symmetric stretching mode and the $\mathrm{SO}_{2}$ deformation frequency that indicate the presence $\mathrm{SO}_{3} \mathrm{H}$ groups attachment on the surface $[10,33]$. The absorption peak of titania impregnation can be observed in Figure $1(\mathrm{c}-\mathrm{h})$. The presence of titania in the catalyst samples can be proven by the presence of absorption peaks around $900-1000 \mathrm{~cm}^{-1}$, which indicated the local stretching mode of $\left[\mathrm{TiO}_{4}\right]$ and/or $\left[\mathrm{O}_{3} \mathrm{TiOH}\right]$ and titanyl $[\mathrm{Ti}=\mathrm{O}]$ vibration [34-36]. But the absorption band of $\mathrm{Ti}-\mathrm{O}$ in this FTIR spectra is indistinct, which is attributed to the

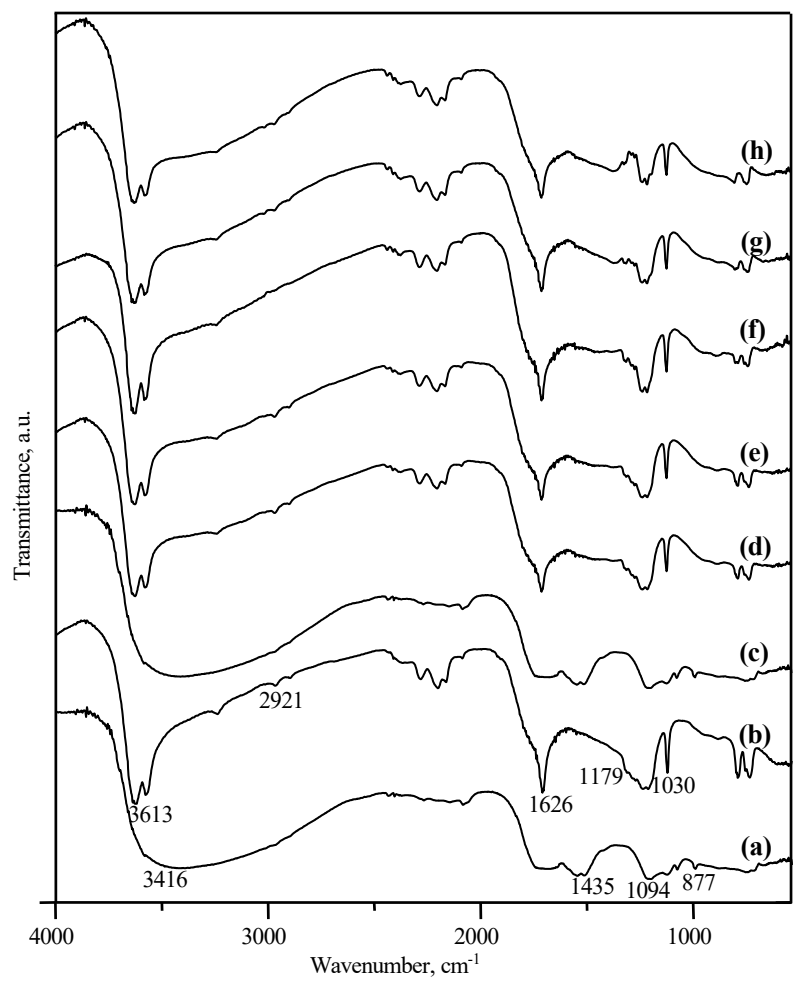

Figure 1. FTIR spectra of (a) FBC500, (b) SFBC500, (c) $\mathrm{TiO}_{2} \quad$ (500)/FBC500, (d) $\mathrm{TiO}_{2}(500) / \mathrm{SFBC} 500,(\mathrm{e}) \mathrm{TiO}_{2}(500) / \mathrm{SFBC} 600$, (f) $\mathrm{TiO}_{2}(500) / \mathrm{SFBC} 700, \quad(\mathrm{~g}) \quad \mathrm{TiO}_{2}(1000) / \mathrm{SFBC} 500$ and (h) $\mathrm{TiO}_{2}(1500) / \mathrm{SFBC} 500$. small amount of titania impregnated onto the sulfonated carbon-derived fish bone.

Figure 2 shows the crystallinity of XRD pattern (a) FBC500, (b) SFBC500, (c) $\mathrm{TiO}_{2}(500) / \mathrm{FBC} 500$, (d) $\mathrm{TiO}_{2}(500) / \mathrm{SCFB} 500$, (e) $\mathrm{TiO}_{2}(500) / \mathrm{SCFB} 600$, (f) $\mathrm{TiO}_{2}(500) / \mathrm{SFBC} 700$, (g)

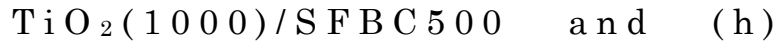
$\mathrm{TiO}_{2}(1500) / \mathrm{SFBC500}$ catalysts. Figures 2(a) and (b) show that FBC500 and SFBC500 catalysts consist the hydroxyapatite which is investigated by the diffraction peaks at $2 \theta=25.8$, 32.0 , and 39.5. Both XRD patterns prove that the sulfonation process did not influence the crystallinity of both catalysts. Figure 2 (c) and (d) could be used to investigate the influence of titania impregnation onto FBC500 and SFBC500 to crystallinity properties. Both XRD patterns show that $\mathrm{TiO}_{2}(500) / \mathrm{FBC} 500$ and $\mathrm{TiO}_{2}(500) / \mathrm{SFBC} 500$ catalysts have the same crystallinity. The effect of varying carbonation

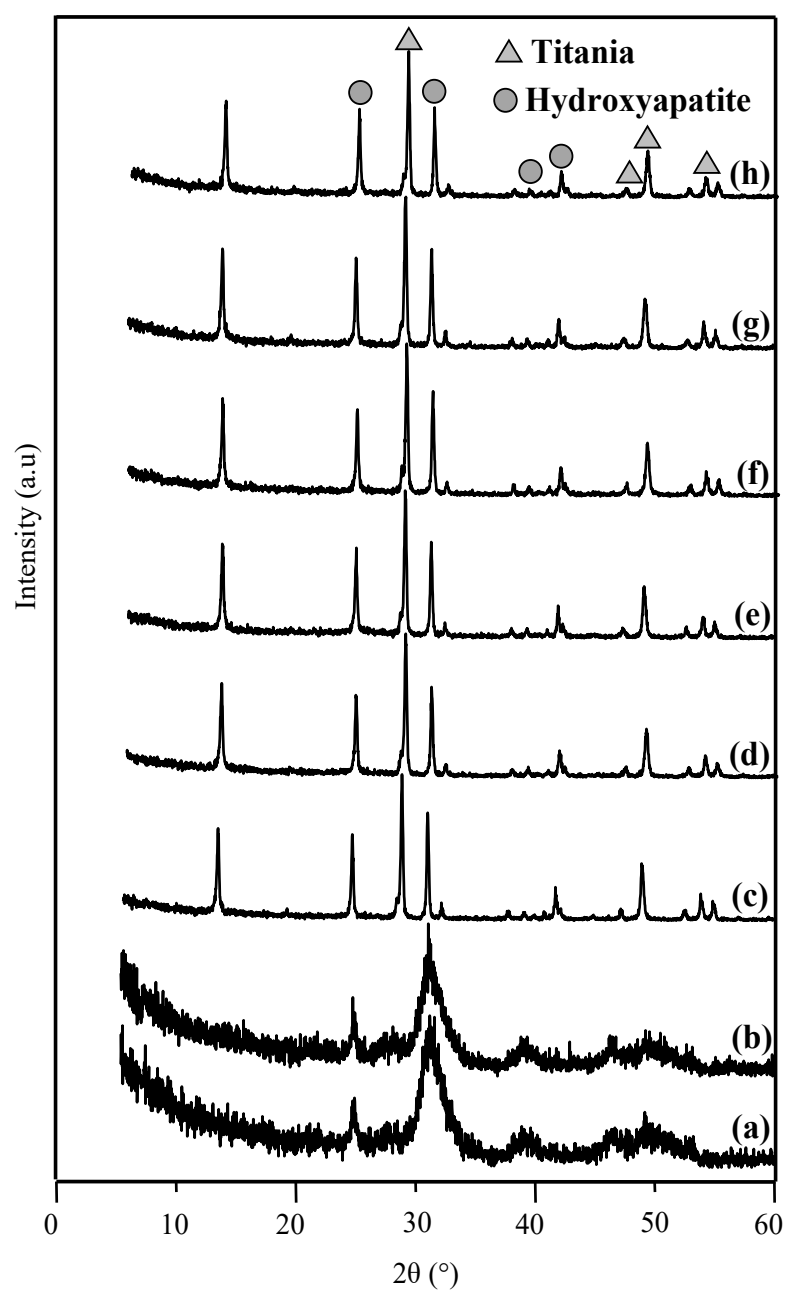

Figure 2. XRD pattern of (a) FBC500, (b) SFBC500, (c) $\mathrm{TiO}_{2} \quad$ (500)/FBC500, (d) $\mathrm{TiO}_{2}$ (500)/SFBC500, (e) $\mathrm{TiO}_{2}(500) / \mathrm{SFBC} 600$, (f) $\mathrm{TiO}_{2}(500) / \mathrm{SFBC} 700$, (g) $\mathrm{TiO}_{2}(1000) / \mathrm{SFBC} 500$ and (h) $\mathrm{TiO}_{2}(1500) / \mathrm{SFBC} 500$. 
temperature of fishbones as support titania catalyst can be shown in Figures 2(d), (e) and (f). The effect of the amount of titania when the impregnation process on the crystallinity properties was investigated from Figure 2(d), (g) and (h). All XRD patterns (c) - (h) show the same crystallinity properties, which were dominated by the diffraction peaks at $2 \theta=29.5$, $31.7,32.9,42.3$, and 52.8 that correlated with the hydroxyapatite and at $2 \theta=25.6,38.5,47.7$, $49.2,54.0$ and 55.2 that assigned to titania [3638 .

The SEM images of (a) FBC500, (b) SFBC500, (c) $\mathrm{TiO}_{2}(500) / \mathrm{FBC} 500, \quad$ (d) $\mathrm{TiO}_{2}(500) / \mathrm{SFBC} 500$, (e) $\mathrm{TiO}_{2}(500) / \mathrm{SFBC} 600$, (f) $\mathrm{TiO}_{2}(500) / \mathrm{SFBC} 700$, (g) $\mathrm{TiO}_{2}(1000) / \mathrm{SFBC} 500$, and (h) $\mathrm{TiO}_{2}(1500) / \mathrm{SFBC} 500$ catalysts are exhibited in Figure 3. It is interesting to note that the effects of the sulfonation process are illustrated in Figures 3 (a) and (b). The irregular shape of (a) FBC500 could be transformed into a cuboid shape after sulfonation, which is labeled as (b) SFBC500. Figures 3 (a) and (c) depict the difference of with and without titania impregnation on FBC500. The roughened sur- face by titania deposition can be seen in Figure 3 (c), but less degree of roughness is found in Figure 3 (a). The titania deposited onto cuboidshaped SFBC500 shows the robustness of the impregnation process in the preparation of $\mathrm{TiO}_{2} / \mathrm{SFBC}$, which is exhibited in Figure 3 (b) and (d) - (h). The existence of S and Ti in EDX data (Table 2) proves that the implementation of the sulfonation and titania impregnation process. It showed the difference between FBC500 and SFBC500, whereby the SFBC500 showed no detection of $\mathrm{Na}, \mathrm{Mg}, \mathrm{P}$ and Si elements. It might be attributed to the sulfonation process that has caused the leaching of $\mathrm{Na}, \mathrm{Mg}, \mathrm{P}$ and Si elements. Additionally, EDX data also showed a similar leaching phenomenon on $\mathrm{TiO}_{2}(500) / \mathrm{FBC} 500$, in which the impregnation process might cause the leaching of $\mathrm{Na}, \mathrm{Ma}$ and Si elements.

Figure 4 shows the nitrogen adsorptiondesorption isotherms of (a) FBC500, (b) $\mathrm{TiO}_{2}(500) / \mathrm{FBC} 500$, and (c) $\mathrm{TiO}_{2}(500) / \mathrm{SFBC} 500$. All isotherms of samples were Type IV in the IUPAC classifications. The typical isotherm was mesoporous materials which were proven
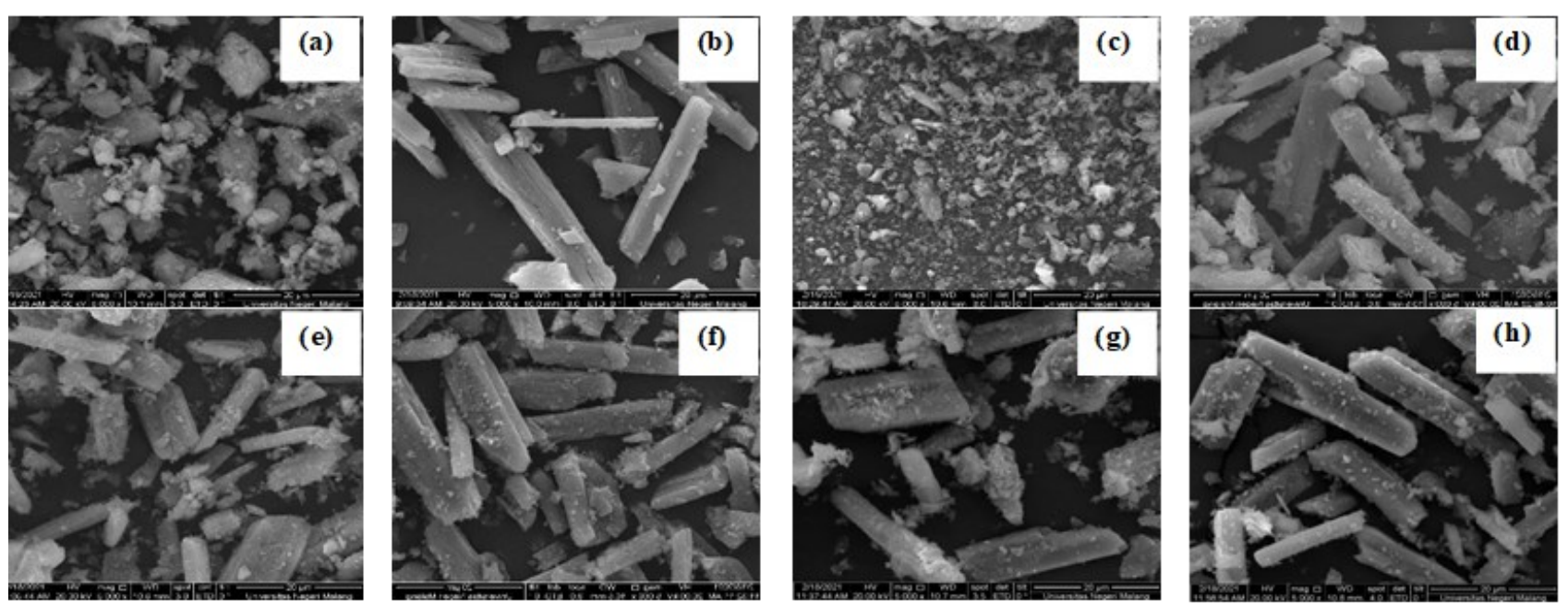

Figure 3. SEM Image of (a) FBC500, (b) SFBC500, (c) $\mathrm{TiO}_{2}$ (500)/FBC500, (d) $\mathrm{TiO}_{2}$ (500)/SFBC500, (e) $\mathrm{TiO}_{2}(500) / \mathrm{SFBC} 600$, (f) $\mathrm{TiO}_{2}(500) / \mathrm{SFBC} 700$, (g) $\mathrm{TiO}_{2}(1000) / \mathrm{SFBC}_{0} 00$ and (h) $\mathrm{TiO}_{2}(1500) / \mathrm{SFBC} 500$.

Table 2. Elements analysis of catalysts using SEM-EDX.

\begin{tabular}{lccccccccc}
\hline \multirow{2}{*}{ Catalysts } & \multicolumn{8}{c}{ Elements concentration (wt\%) } \\
\cline { 2 - 10 } & $\mathrm{C}$ & $\mathrm{O}$ & $\mathrm{Na}$ & $\mathrm{Mg}$ & $\mathrm{Si}$ & $\mathrm{P}$ & $\mathrm{Ca}$ & $\mathrm{Ti}$ & $\mathrm{S}$ \\
\hline FBC500 & 20.55 & 34.34 & 1.71 & 0.63 & 0.44 & 12.91 & 28.91 & 0.52 & - \\
$\mathrm{SFBC500}_{\mathrm{TiO}_{2}(500) / \text { FBC500 }}$ & 10.31 & 33.45 & - & - & - & - & 30.96 & 0.31 & 24.97 \\
$\mathrm{TiO}_{2}(500) /$ SFBC500 & 32.39 & 37.28 & - & - & - & 6.82 & 13.61 & 2.98 & - \\
$\mathrm{TiO}_{2}(500) /$ SFBC600 & 24.50 & 34.98 & - & - & - & - & 17.61 & 1.65 & 14.63 \\
$\mathrm{TiO}_{2}(500) /$ SFBC700 & 30.95 & 36.28 & - & - & - & - & 22.41 & 0.98 & 17.14 \\
$\mathrm{TiO}_{2}(1000) /$ SFBC500 & 41.52 & 33.32 & - & - & - & - & 17.47 & 0.98 & 14.32 \\
$\mathrm{TiO}_{2}(1500) /$ SFBC500 & 35.37 & 34.33 & - & - & - & - & 13.73 & 1.31 & 10.12 \\
\hline
\end{tabular}


by the knee area. The sulfonation and titania impregnation process do not influence the type of mesoporous properties. The sulfonation process only influenced the hysteresis loops that become narrow. It correlated to decrease surface area after the sulfonation process. The BET surface area, pore-volume, and mean pore size of FBC500, $\mathrm{SFBC}_{000}, \mathrm{TiO}_{2}(500) / \mathrm{FBC} 500$, $\mathrm{TiO}_{2}(500) / \mathrm{SFBC} 500, \quad \mathrm{TiO}_{2}(500) / \mathrm{SFBC} 600$, $\mathrm{TiO}_{2}(500) / \mathrm{SFBC} 700, \mathrm{TiO}_{2}(1000) / \mathrm{SFBC} 500$ and $\mathrm{TiO}_{2}(1500) / \mathrm{SFBC500}$ were obtained from the nitrogen adsorption-desorption analysis. The complete data are listed in Table 3. The pore size distribution of all samples is more than 2

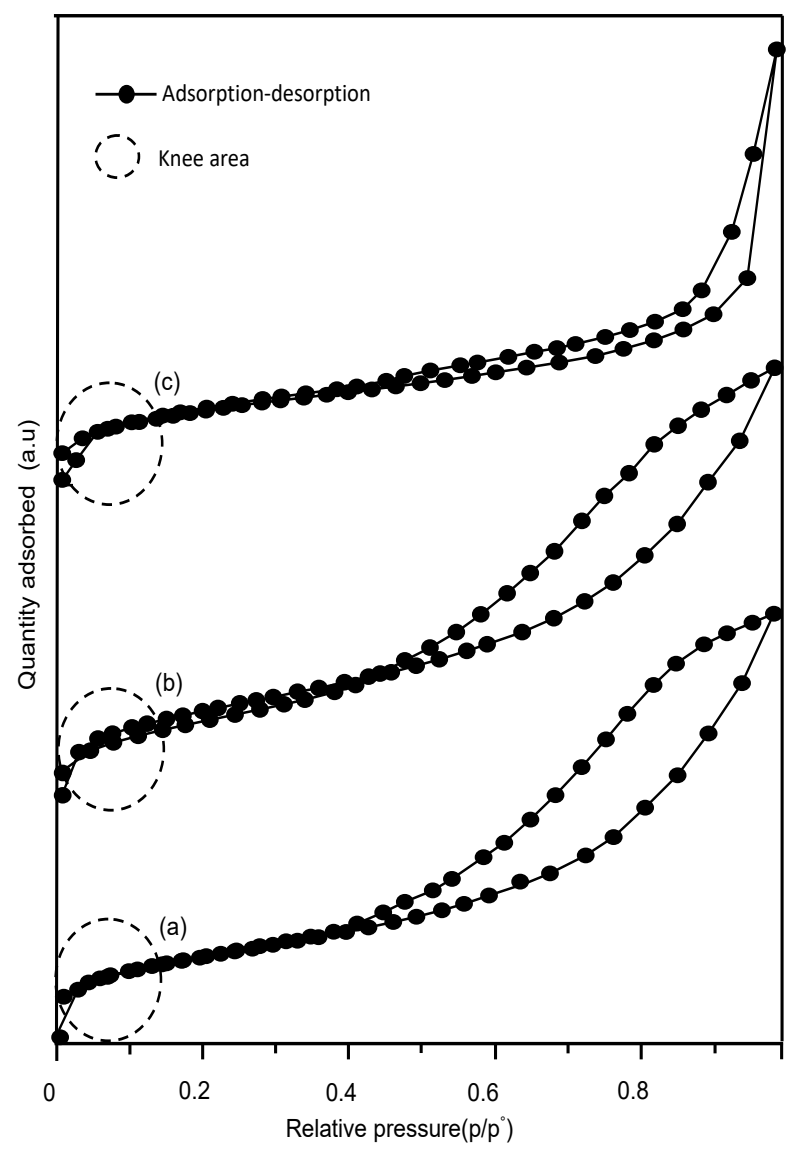

Figure 4. The physisorption isotherms of (a) FBC500, (b) $\mathrm{TiO}_{2}$ (500)/FBC500, and (c) $\mathrm{TiO}_{2}(500) / \mathrm{SFBC} 500$. $\mathrm{nm}$, indicating the presence of uniform mesopores. The BET surface area and pore volume showed the following values; $106.4 \mathrm{~m}^{2} \cdot \mathrm{g}^{-1}$, $0.249 \mathrm{~cm}^{3} \cdot \mathrm{g}^{-1}$ for CFB500; $6.8 \mathrm{~m}^{2} . \mathrm{g}^{-1}, 0.0147$ $\mathrm{cm}^{3} \cdot \mathrm{g}^{-1}$ for SFBC500. In this phenomenon the sulfonation process can dissolve the small particles evidenced by SEM images, whereby the small particles (Figure 3(a)) are transformed into cuboid shape (Figure 3(b)), thus decreasing the BET surface area and pore volume. On the other hand, titanium impregnation SFBC could increase the BET surface area and pore volume, as shown in Table 3. The surface area and pore volume are listed as such: $6.8 \mathrm{~m}^{2} \cdot \mathrm{g}^{-1}$, $0.0147 \mathrm{~cm}^{3} \cdot \mathrm{g}^{-1}$ for SFBC500; and $13.9 \mathrm{~m}^{2} \cdot \mathrm{g}^{-1}$, $0.0350 \mathrm{~cm}^{3} \cdot \mathrm{g}^{-1}$ for $\mathrm{TiO}_{2}(500) / \mathrm{SFBC} 500$. An increase amount of titanium impregnated onto the support can sequentially increase the BET surface area and pore volume, as indicated with $\quad 13.9 \quad \mathrm{~m}^{2} \cdot \mathrm{g}^{-1}, \quad 0.035 \quad \mathrm{~cm}^{3} \cdot \mathrm{g}^{-1}$ for $\mathrm{TiO}_{2}(500) / \mathrm{SFBC} 500 ; 23.3 \mathrm{~m}^{2} \cdot \mathrm{g}^{-1}, 0.0352 \mathrm{~cm}^{3} \cdot \mathrm{g}^{-1}$ for $\mathrm{TiO}_{2}(1000) / \mathrm{SFBC} 500$; and $33.1 \mathrm{~m}^{2} \cdot \mathrm{g}^{-1}$, $0.0540 \mathrm{~cm}^{3} \cdot \mathrm{g}^{-1}$ for $\mathrm{TiO}_{2}(1500) / \mathrm{SFBC} 500$.

\subsection{Catalytic Activity}

The yields of styrene oxidation with $\mathrm{H}_{2} \mathrm{O}_{2}$ as oxidant catalyzed by $\mathrm{TiO}_{2}, \mathrm{FBC} 500$, SFBC500, $\mathrm{TiO}_{2}(500) / \mathrm{FBC} 500, \quad \mathrm{TiO}_{2}(500) / \mathrm{SFBC} 500$, $\mathrm{TiO}_{2}(500) / \mathrm{SFBC} 600, \quad \mathrm{TiO}_{2}(500) / \mathrm{SFBC} 700$, $\mathrm{TiO}_{2}(1000) / \mathrm{SFBC} 500$ and $\mathrm{TiO}_{2}(1500) / \mathrm{SFBC} 500$ catalysts can be shown in histogram of Figure 5. The styrene conversion over no catalyst, $\mathrm{TiO}_{2}, \mathrm{FBC} 500, \quad \mathrm{SFBC} 500, \mathrm{TiO}_{2}(500) / \mathrm{FBC} 500$, $\mathrm{TiO}_{2}(500) / \mathrm{SFBC} 500, \quad \mathrm{TiO}_{2}(500) / \mathrm{SFBC} 600$, $\mathrm{TiO}_{2}(500) / \mathrm{SFBC} 700, \mathrm{TiO}_{2}(1000) / \mathrm{SFBC} 500$ and $\mathrm{TiO}_{2}(1500) / \mathrm{SFBC} 500$ catalysts are $2.9 ; 3.2 ; 0.3$; $0.2 ; 5.3 ; 17.1 ; 18.5 ; 16.0$; 38.9 and $51.1 \%$, respectively. The role of catalyst support can be proven by styrene conversion of $\mathrm{TiO}_{2}, \mathrm{FBC} 500$, SFBC500, $\mathrm{TiO}_{2}(500) / \mathrm{FBC} 500$, and $\mathrm{TiO}_{2}(500) / \mathrm{SFBC} 500$ as catalysts. The styrene conversion of metal catalyst $\left(\mathrm{TiO}_{2}\right)$ and support catalyst (FBC500, and SFBC500) in styrene oxidation showed lower activity than titania supported fish bone-derived carbon

Table 3. Physical properties of the catalysts.

\begin{tabular}{lccc}
\multicolumn{1}{c}{ Samples } & BET surface area $\left(\mathrm{m}^{2} / \mathrm{g}\right)$ & Pore Volume $\left(\mathrm{cm}^{3} / \mathrm{g}\right)$ & Mean pore size $(\mathrm{nm})$ \\
\hline FBC500 & 106.4 & 0.249 & 4.7 \\
$\mathrm{SFBC500}_{\mathrm{TiO}_{2}(500) / \text { FBC500 }}$ & 6.8 & 0.0147 & 4.3 \\
$\mathrm{TiO}_{2}(500) /$ SFBC500 & 13.8 & 0.0532 & 7.7 \\
$\mathrm{TiO}_{2}(500) /$ SFBC600 & 13.9 & 0.0350 & 5.0 \\
$\mathrm{TiO}_{2}(500) /$ SFBC700 & 15.4 & 0.0339 & 4.4 \\
$\mathrm{TiO}_{2}(1000) /$ SFBC500 & 19.6 & 0.0389 & 4.0 \\
$\mathrm{TiO}_{2}(1500) /$ SFBC500 & 23.3 & 0.0352 & 3.0 \\
\hline
\end{tabular}


$\left(\mathrm{TiO}_{2}(500) / \mathrm{FBC} 500\right.$, and $\left.\mathrm{TiO}_{2}(500) / \mathrm{SFBC} 500\right)$. The effect of the sulfonation process on catalyst support can be shown when $\mathrm{TiO}_{2}(500) / \mathrm{FBC} 500$, and $\mathrm{TiO}_{2}(500) / \mathrm{SFBC500}$ were used as catalysts. The sulfonation process to catalyst support can increase the styrene conversion and benzaldehyde selectivity, which proven by styrene conversion and benzaldehyde selectivity over $\left.\mathrm{TiO}_{2}(500) / \mathrm{SFBC} 500\right)$ was $17.1 \%$ and $86.0 \%$, respectively; while $\mathrm{TiO}_{2}(500) / \mathrm{FBC} 500$ gave only $5.3 \%$ and $3.0 \%$, respectively. A sulfonate group is a polar group for $\mathrm{H}_{2} \mathrm{O}_{2}$ adsorption while carbonized hydroxyapatite is a nonpolar group for styrene adsorption. By lowering the mass transfer resistance, titania (the catalytic active sites) could convert styrene to benzaldehyde after both styrene and $\mathrm{H}_{2} \mathrm{O}_{2}$ adsorbed nearby. The varying carbonization temperature of catalyst support showed similar catalytic conversion in this study, evidenced by $\mathrm{TiO}_{2}(500) / \mathrm{SFBC} 500, \mathrm{TiO}_{2}(500) / \mathrm{SFBC} 600$, and $\mathrm{TiO}_{2}(500) / \mathrm{SFBC} 700$ gave $17.1 \%, 18.5 \%$, and $16 \%$, respectively. An insignificant increase of surface area resulted in less impregnation of titania active sites onto the support surface. The effect of the varying amount of metal titanium that impregnated onto catalyst support can be investigated based on the styrene conversion $\mathrm{w}$ h e $\mathrm{n} \quad \mathrm{Ti} \mathrm{O}_{2}\left(\begin{array}{lll}5 & 0 & 0\end{array}\right) / \mathrm{S} \mathrm{F} \mathrm{B} \mathrm{C} 500$, $\mathrm{TiO}_{2}(1000) / \mathrm{SFBC} 500$ and $\mathrm{TiO}_{2}(1500) / \mathrm{SFBC} 500$ were used as catalysts. The increasing of the amount of metal titanium as the active site from 500 to $1500 \mu \mathrm{mol}$ in the catalyst can in-

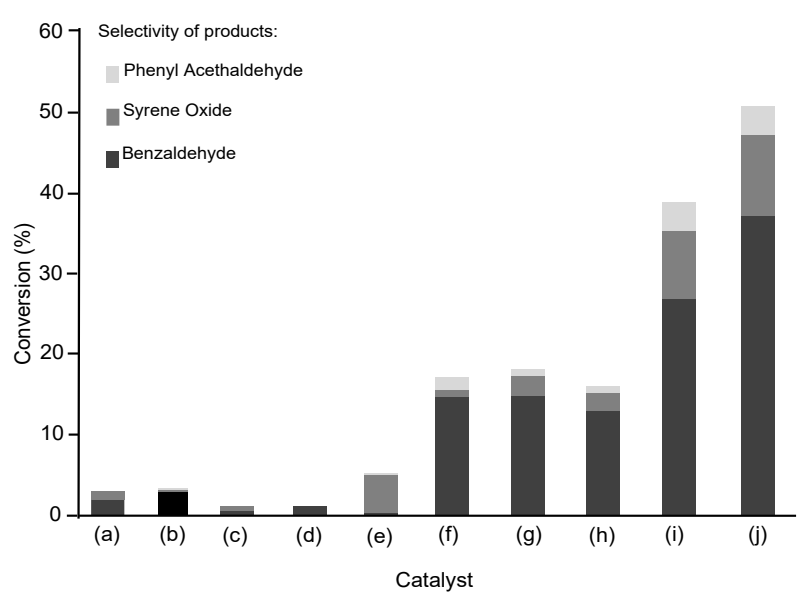

Figure 5. Comparison of catalytic performance of (a) no catalyst, (b) $\mathrm{TiO}_{2}$, (c) FBC500, (d) SFBC500, (e) $\mathrm{TiO}_{2}(500) / \mathrm{FBC} 500, \quad$ (f) $\mathrm{TiO}_{2}(500) / \mathrm{SFBC} 500, \quad$ (g) $\mathrm{TiO}_{2}(500) / \mathrm{SFBC} 600$, (h) $\quad \mathrm{TiO}_{2}\left(\begin{array}{lll}500 & 0\end{array}\right) / \mathrm{S} F \mathrm{BC} 700$, (i)

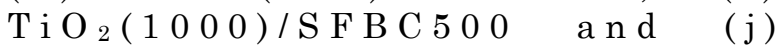
$\mathrm{TiO}_{2}(1500) / \mathrm{SFBC} 500$ catalysts in the oxidation of styrene $(5 \mathrm{mmol}), 30 \% \mathrm{H}_{2} \mathrm{O}_{2}(5 \mathrm{mmol})$ and catalyst $(50 \mathrm{mg})$ at room temperature for $24 \mathrm{~h}$. crease styrene conversion from 17.1 to $51.1 \%$. This result is in agreement with the previous research when styrene oxidation with $\mathrm{H}_{2} \mathrm{O}_{2}$ as an oxidant was catalyzed with titanium dioxide-supported sulfonated low-rank coal [18].

In order to check the reusability and stability of the catalyst which have been created, $\mathrm{TiO}_{2}(1500) / \mathrm{SFBC} 500$ catalyst was selected for the assessment. $\mathrm{TiO}_{2}(1500) / \mathrm{SFBC} 500$ catalyst was recovered and recycled for further reaction. The spent catalyst was washed with ethanol and then centrifuged thrice and drying at $110{ }^{\circ} \mathrm{C}$ in a vacuum oven overnight. The styrene conversion was used as a basis to compare every reaction cycle. As shown in Figure 6, it is seen that the decreasing of the styrene conversion for the respective first, second and third reaction cycles, i.e. 51.1, 48.4 and $40.8 \%$. The decreasing of the styrene conversion might be due to the physical detachment of some catalyst powder during mechanical stirring. Moreover, another possible explanation for decreasing of the activity is the leaching out of titania active sites of the pores during the washing process by ethanol solvent [11,39]. The selectivity of benzaldehyde for the first, second, and third cycles are almost similar, i.e. 70.8, 70.1, and $75.6 \%$, respectively. It is because the sulfonate groups of $\mathrm{TiO}_{2}(1500) / \mathrm{SFBC} 500$ are still accessible for the high selectivity of benzaldehyde at room temperature. The effectiveness of sulfonate group to achieve high selectivity of benzaldehyde is evidenced in Figure 5(d), i.e. $\sim 100 \%$ benzaldehyde selectivity. This can be explained that low concentration of titania en-

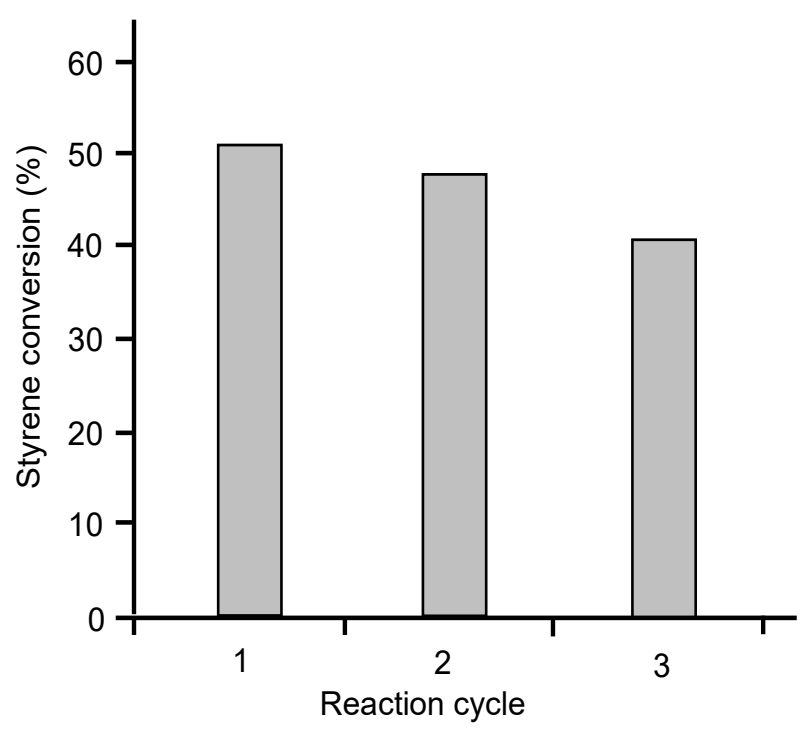

Figure 6. The reuse of $\mathrm{TiO}_{2}(1500) / \mathrm{SFBC} 500$ catalysts in the oxidation of styrene $(5 \mathrm{mmol})$, $30 \% \mathrm{H}_{2} \mathrm{O}_{2}(5 \mathrm{mmol})$ and catalyst $(100 \mathrm{mg})$ at room temperature for $24 \mathrm{~h}$. 
hances benzaldehyde selectivity. Nonetheless, the role of titania cannot be neglected as it could increase the conversion rate of styrene.

\subsection{Kinetic Model: the Power-rate Law}

The power-rate law is chosen as a kinetic model to determine the rate constant $(k)$ and reaction behavior of a reaction using a function of temperature and concentration. A series kinetic experiment of styrene oxidation by $\mathrm{H}_{2} \mathrm{O}_{2}$ was performed at various temperatures (303, 313 and $323 \mathrm{~K})$ with acetonitrile as solvent. The power-rate law can be represented as [40,41]:

$r_{i}=-\frac{d C_{i}}{d t}=k K_{1} K_{2}[$ catalyst $][$ Styrene $]\left[\mathrm{H}_{2} \mathrm{O}_{2}\right]^{1 / 2}$

$r_{i}=-\frac{d\left[C_{0}-x\right]}{d t}=k K_{1} K_{2}[$ catalyst $][$ Styrene $]\left[H_{2} O_{2}\right]^{1 / 2}$

$r_{i}=\frac{d x}{d t}=k K_{1} K_{2}[$ catalyst $][$ Styrene $]\left[H_{2} O_{2}\right]^{1 / 2}$

where, $r_{i}$ is the reaction rate of the styrene oxidation $\left(\mathrm{mol} . \mathrm{cm}^{-3} \cdot \mathrm{s}^{-1}\right) ; k$ is the reaction rate constant $\left(\mathrm{min}^{-1}\right) ; C_{i}$ is styrene concentration after oxidation time $t\left(\mathrm{~mol}_{\mathrm{cm}} \mathrm{cm}^{-3}\right)$; catalyst] is the concentration of $\mathrm{TiO}_{2}(1500) / \mathrm{SFBC} 500$ catalyst and $K_{1}$ and $K_{2}$ are pre-equilibrium constants of the step in the Schema.

If the total catalyst concentration is ex-

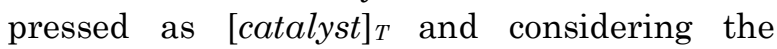
steady-state approach, which includes the con- centration of all the intermediate catalyst species, the power-rate law can be given as:

$$
\begin{aligned}
& r_{i}=\frac{k K_{1} K_{2}[\text { catalyst }][\text { Styrene }]\left[\mathrm{H}_{2} \mathrm{O}_{2}\right]^{1 / 2}}{1+K_{1}\left[\mathrm{H}_{2} \mathrm{O}_{2}\right]^{1 / 2}+K_{1} K_{2}[\text { Styrene }]\left[\mathrm{H}_{2} \mathrm{O}_{2}\right]^{1 / 2}} \\
& \frac{[\text { catalyst }]_{T}}{r_{i}}=\frac{1+K_{1}\left[\mathrm{H}_{2} \mathrm{O}_{2}\right]^{1 / 2}+K_{1} K_{2}[\text { Styrene }]\left[\mathrm{H}_{2} \mathrm{O}_{2}\right]^{1 / 2}}{k K_{1} K_{2}[\text { Styrene }]\left[\mathrm{H}_{2} \mathrm{O}_{2}\right]^{1 / 2}} \\
& \frac{[\text { catalyst }]_{T}}{r_{i}}=\frac{1}{[\text { Styrene }]}\left\{\frac{1}{k K_{1} K_{2}\left[\mathrm{H}_{2} \mathrm{O}_{2}\right]^{1 / 2}}+\frac{1}{k K_{2}}\right\}+\frac{1}{k}
\end{aligned}
$$

The value of rate constant $k$ was determined of the intercept from the plot of $[\text { catalyst }]_{T} / r_{i}$ vs $1 /[$ styrene $]$.

The kinetic data obtained from styrene oxidation with $\mathrm{H}_{2} \mathrm{O}_{2}$ as oxidant onto $\mathrm{TiO}_{2}(1500) / \mathrm{SFBC500}$ are shown in Table 4. Base on the experiment results, the styrene oxidation over $\mathrm{TiO}_{2}(1500) / \mathrm{SFBC} 500$ catalyst follows first-order reaction model. The rate constant $(k)$ at 303,313 , and $323 \mathrm{~K}$ were reported as $0.000512,0.00299$, and $0.00339 \mathrm{~min}^{-1}$, respectively. The value of the rate constant can be used to predict the rate of reaction. Higher the rate constant, faster is the reaction rate. In details, it can be concluded that the rate of styrene oxidation increases with the reaction temperature.

The activation energy $(E)$ of styrene oxidation with $\mathrm{H}_{2} \mathrm{O}_{2}$ as oxidant in the presence of $\mathrm{TiO}_{2}(1500) / \mathrm{SFBC} 500$ was investigated with the Arrhenius law, which the equation is written

\begin{tabular}{|c|c|c|c|c|c|c|c|c|c|}
\hline \multirow{2}{*}{$\begin{array}{c}\text { Temp. } \\
\text { (K) }\end{array}$} & & \multicolumn{6}{|c|}{ Time (min) } & \multirow{2}{*}{$\begin{array}{c}\text { Rate } \\
\text { constant of } \\
\text { First Order, } \\
k\left(\min ^{-1}\right)\end{array}$} & \multirow{2}{*}{$\begin{array}{c}\text { Activation } \\
\text { Energy, } \\
E_{a}(\mathrm{~kJ})\end{array}$} \\
\hline & & 0 & 30 & 60 & 120 & 180 & 240 & & \\
\hline \multirow{3}{*}{303} & $x$ & 0 & 0.0063 & 0.0465 & 0.0083 & 1100 & 0.1118 & \multirow{3}{*}{$5.12 \times 10^{-4}$} & \multirow{9}{*}{63.485} \\
\hline & $C_{i}$ & 0.8944 & 0.8882 & 0.8479 & 0.8211 & 0.7844 & 0.7826 & & \\
\hline & $\frac{\partial x}{\partial t}$ & 0 & $2.08 \times 10^{-4}$ & $7.75 \times 10^{-4}$ & $6.93 \times 10^{-5}$ & $6.11 \times 10^{-4}$ & $4.66 \times 10^{-4}$ & & \\
\hline \multirow{3}{*}{313} & $x$ & 0 & 0.0152 & 0.0814 & 0.1091 & 0.1368 & 0.1583 & \multirow{3}{*}{$2.99 \times 10^{-3}$} & \\
\hline & $C_{i}$ & 0.8944 & 0.8792 & 0.8131 & 0.7853 & 0.7576 & 0.7361 & & \\
\hline & $\frac{\partial x}{\partial t}$ & 0 & $5.07 \times 10^{-4}$ & $1.36 \times 10^{-3}$ & $9.09 \times 10^{-4}$ & $7.60 \times 10^{-4}$ & $6.59 \times 10^{-4}$ & & \\
\hline \multirow{3}{*}{323} & $x$ & 0 & 0.0465 & 0.0733 & 0.0787 & 0.1234 & 0.1816 & \multirow{3}{*}{$3.39 \times 10^{-3}$} & \\
\hline & $C_{i}$ & 0.8944 & 0.8479 & 0.8211 & 0.8157 & 0.771 & 0.7129 & & \\
\hline & $\frac{\partial x}{\partial t}$ & 0 & $1.55 \times 10^{-3}$ & $1.22 \times 10^{-3}$ & $6.56 \times 10^{-4}$ & $6.86 \times 10^{-4}$ & $7.56 \times 10^{-4}$ & & \\
\hline
\end{tabular}
as [42]:

Table 4. First order kinetics of styrene oxidation onto $\mathrm{TiO}_{2}(1500) / \mathrm{SCFB} 500$ catalysts.

(Conditions: $5 \mathrm{mmol}$ styrene $=0.5806 \mathrm{~mL} ; 5 \mathrm{mmol} \mathrm{H} \mathrm{O}_{2}=0.5107 \mathrm{~mL}$; Acetonitrile $=4.5 \mathrm{~mL}$ and catalyst $=100 \mathrm{mg}$ ). 


$$
k=A e^{-\frac{E}{R T}}
$$

where $k, A$ and $\exp [-E /(R T)]$ are rate constant, frequency factor and the Boltzmann expression for the fraction of systems having energy in excess of the value $E$ (the fraction of the reactant molecules), respectively.

Equation (7) can be rearranged to linear form as:

$$
\ln k=\ln A-\frac{E}{R T}
$$

The plotting $\ln k$ against $1 / T$ with the slope is $-E / R$, so that the activation energy can be calculated. The activation energy of styrene oxidation with $\mathrm{H}_{2} \mathrm{O}_{2}$ as oxidant onto $\mathrm{TiO}_{2}(1500) / \mathrm{SFBC} 500$ was $63.485 \mathrm{~kJ}$.

It is interesting to compare the activation energy of titania sulfonated fish bone-derived carbon with the results of other studies. In general, the activation energy of chemical reactions in the presence of a solid catalyst in liquid-phase oxidation of styrene with hydrogen peroxide is in the range of $20-80 \mathrm{~kJ}$ [43]. The results obtained in this research work are in agreement with these results, suggesting that a low-cost fish bone-derived carbon can be used as a catalyst.

\section{Conclusions}

The styrene oxidation by $\mathrm{H}_{2} \mathrm{O}_{2}$ oxidant over titania fish bone-derived carbon has been demonstrated in this research. The sulfonation with $\mathrm{H}_{2} \mathrm{SO}_{4}(1 \mathrm{M})$ can transform the particulate shape of FBC500 into the cuboid shape of SFBC500. The catalysts surface area was not the determinant in this catalytic reaction. Regardless of the smaller surface area of $\mathrm{TiO}_{2} / \mathrm{SBFC}$, the titania impregnation and fish bone-derived carbon sulfonation improved styrene conversion and gave high benzaldehyde selectivity. The impregnation titania $\left(\mathrm{TiO}_{2}\right)$ onto fish bone-derived carbon changed the physical properties and catalytic activity. The amorphous structure of FBC and SFBC were changed to crystalline structure after the impregnation of titania. Higher the amount of titania impregnated onto sulfonated fish bonederived carbon, higher the catalytic oxidation of styrene by $\mathrm{H}_{2} \mathrm{O}_{2}$. Increasing of the carbonization temperature of sulfonated fish bonederived carbon barely affected the catalytic activity. The kinetic data of styrene oxidation by $\mathrm{H}_{2} \mathrm{O}_{2}$ followed the first-order reaction model, whereby the reaction rate increases with increasing of reaction temperature. The activation energy of the styrene oxidation reaction over $\mathrm{TiO}_{2}(1500) / \mathrm{SFBC500}$ catalyst was reported as $63.5 \mathrm{~kJ}$, falling within the range of other typical catalysts. To advocate the green materials synthesis and economic sustainability, this research work successfully demonstrated the styrene oxidation by engineered low-cost fish bone catalysts.

\section{Acknowledgements}

The authors gratefully acknowledge research grant Direktorat Riset dan Pengabdian Masyarakat Deputi Bidang Penguatan Riset dan Pengembangan Kementerian Riset dan Teknologi/Badan Riset dan Inovasi TA. 2021 by contract number: 590/UN17.L1/PG/2021.

\section{References}

[1] Aberkouks, A., Mekkaoui, A.A., Boualy, B., Houssame, S.E., Ali, M.A., Firdoussi, L.E. (2018). Selective Oxidation of Styrene to Benzaldehyde by Co-Ag Codoped $\mathrm{ZnO}$ Catalyst and $\mathrm{H}_{2} \mathrm{O}_{2}$ as Oxidant. Adv. Mater. Sci. Eng., 2018, 7. DOI: 10.1155/2018/2716435

[2] Qi, B., Lu, X.H., Zhou, D., Xia, Q.H., Tang, Z.R., Fang, S.Y., Pang, T., Dong, Y.L., (2010). Catalytic epoxidation of alkenes with $30 \%$ $\mathrm{H}_{2} \mathrm{O}_{2}$ over $\mathrm{Mn}^{2+}$-exchanged zeolites. J. Mol. Catal. A: Chem., 322(1-2), 73-79. DOI: 10.1016/j.molcata.2010.02.019

[3] Zhan, W., Guo, Y., Wang, Y., Guo, Y., Liu, Y.X., Wang, Y., Zhang, Z., Lu, G. (2009). Study of Higher Selectivity to Styrene Oxide in the Epoxidation of Styrene with Hydrogen Peroxide over La-Doped MCM-48 Catalyst. J. Phys. Chem. C, 113(17), 7181-7185. DOI: 10.1021/jp8101095

[4] Nurhadi, M., Kusumawardani, R., Wirawan, T., Sumari, S., Yuan, L.S., Nur, H. (2021). Catalytic Performance of $\mathrm{TiO}_{2}-$ Carbon Mesoporous_Derived from Fish Bones in Styrene Oxidation with Aqueous Hydrogen Peroxide as an Oxidant. Bull. Chem. React. Eng. C a t a l. , $\quad 16$ ( 1 ), $88-96$. DOI: $10.9767 /$ bcrec.16.1.9729.88-96

[5] Liu, L., He, W., Fang, Z., Yang, Z., Guo, K., Wang, Z. (2020). From Core-Shell to Yolk-Shell: Improved Catalytic Performance toward $\mathrm{CoFe}_{2} \mathrm{O}_{4} @$ Hollow@ Mesoporous $\mathrm{TiO}_{2}$ toward Selective Oxidation of Styrene. Ind. Eng. Chem. Res., 59(45), 19938-19951. DOI: 10.1021/acs.iecr.0c03884

[6] Sakthivel, B., Josephine, D.S.R., Sethuraman, K., Dhakshinamoorthy, A. (2018). Oxidation of styrene using $\mathrm{TiO}_{2}$-graphene oxide composite as solid heterogeneous catalyst with hydroperoxide as oxidant. Catal. Com-

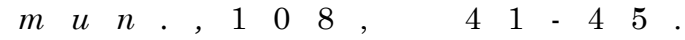
DOI: $10.1016 /$ j.catcom.2018.01.029 
[7] Milovac, D., Weigand, I., Kova ci'c, M., Ivankovi'c, M., Ivankovi'c, H. (2018). Highly porous hydroxyapatite derived from cuttlefish bone as $\mathrm{TiO}_{2}$ catalyst support. Proces. Appl. Ceramics, 12(2), 136-142. DOI: 10.2298/PAC1802136M.

[8] Puma, G.L., Bono, A., Krishnaiah, D., Collin, J.G. (2008). Preparation of titanium dioxide photocatalyst loaded onto activated carbon support using chemical vapor deposition: A review paper. J. Hazard. Mater., 157(2-3), 209-219. DOI: 10.1016/j.jhazmat.2008.01.040

[9] Ito, S., Kon, Y., Nakashima, T., Hong, D., Konno, H., Ino, D., Sato, K. (2019). TitaniaCatalyzed $\mathrm{H} 2 \mathrm{O} 2$ Thermal Oxidation of Styrenes to Aldehydes. Molecules, 24(14), 1-9. DOI: $10.3390 /$ molecules24142520

[10] Nurhadi, M., Chandren, S., Yuan, L.S., Ho, C.S., Mahlia, T.M.I., Nur, H. (2017). TitaniaLoaded Coal Char as Catalyst in Oxidation of Styrene with Aqueous Hydrogen Peroxide. Inter. J. Chem. Reactor Eng., 15(1), 45-55. DOI: 10.1515/ijcre-2016-0088.

[11] Nurhadi, M. (2017). Modification of Coal Char-loaded $\mathrm{TiO}_{2}$ by Sulfonation and Alkylsilylation to Enhance Catalytic Activity in Styrene Oxidation with Hydrogen Peroxide as Oxidant. Bull. Chem. React. Eng. Catal., 12(1), 55-61. DOI: 10.9767/bcrec.12.1.501.5561

[12] Lubis, S., Yuliati, L., Lee, S.L., Sumpono, I., Nur, H. (2012). Improvement of catalytic activity in styrene oxidation of carbon-coated titania by formation of porous carbon layer. Chem. Eng. J., 209, 468-493. DOI: 10.1016/j.cej.2012.08.041

[13] Lubis, S. (2013). Porous Carbon-Coated Titania Prepared by In-Situ Polymerization of Styrene and Its Catalytic and Photocatalytic Activities Oxidation of Alkenes. Ph.D. Dissertation, Department of Chemistry Science, Universiti Teknologi Malaysia.

[14] Zhuang, J., Ma, D., Yan, Z., Liu, X., Han, X., Bao, X., Zhang, Y., Guo, X., Wang, X. (2004). Effect of acidity in TS-1 zeolites on product distribution of the styrene oxidation reaction. Appl. Catal. A-Gen., 258(1), 1-6. DOI: 10.1016/j.apcata.2003.06.002

[15] Lin, K., Pescarmona, P.P., Houthoofd, K., Liang, D., Van Tendeloo, G., Jacobs, P.A. (2009). Direct room-temperature synthesis of methyl-functionalized Ti-MCM-41 nanoparticles and their catalytic performance in epoxidation. J. Catal., 263(1), 75-82. DOI: 10.1016/j.jcat.2009.01.013
[16] Modak, A., Nandi, M., Bhaumik, A. (2012). Titanium containing periodic mesoporous organosilica as an efficient catalyst for the epoxidation of alkenes. Catal. Today, 198(1), 45-51. DOI: 10.1016/j.cattod.2012.03.074

[17] Parvulescu, V., Anastasescu, C., Constantin, C., Su, B.L. (2003). Mono (V,Nb) or bimetallic (V-Ti, Nb-Ti) ions modified MCM-41 catalysts: synthesis, characterization and catalysis in oxidation of hydrocarbons (aromatics and alcohols). Catal. Today, 78(1-4), 477-485. DOI: 10.1016/S0920-5861(02)00330-9

[18] Nurhadi, M., Efendi, J., Ling, L.S., Mahlia, T.M.I., Siong, H.C., Yuan, L.S., Chandren, S., Nur, H. (2014). Titanium Dioxide-Supported Sulfonated Low Rank Coal as Catalysts in the Oxidation of Styrene with Aqueous Hydrogen Peroxide. J Teknologi, 69(5), 71-79. DOI: $10.11113 /$ jt.v69.3208.

[19] Dwiwarno, N., Setyawanta, L.T., Saraswati, R. (2021). Sustainability Management and Planning of Coastal Areas and Small Islands to Ensure Environmental Justice for Fishermen Communities. J. Environ. Treat. Tech, 9(1), 117-121. DOI: 10.47277/JETT/9(1)121.

[20] Fishery and Aquaculture Country Profiles. Indonesia. Country Profile Fact Sheets. Fisheries and Aquaculture Division (July 2014). Citing Internet sources (3 Feb 2022) URL: https://www.fao.org/fishery/en/facp/idn?lang= en.

[21] Halim, D., Juanri, J. (31 August 2016). Indonesia's aquaculture industry: Key sectors for future growth. Citing Internet sources (accessed on 3 February 2022) URL https://www.ipsos.com/en/indonesias aquaculture-industry-key-sectors-futuregrowth\#: :text=In\%20fact $\% 2 \mathrm{C} \% 20 \mathrm{it} \% 20 \mathrm{is} \% 2$ 0estimated, $0.4 \% 25 \% 20$ over $\% 20 \mathrm{a} \% 20$ similar $\%$ 20period.

[22] Coppola, D., Lauritano, C., Esposito, F.P., Riccio, G., Rizzo, C., Pascale, D. (2021). Fish waste: From problem to valuable resource. Marine Drugs, 19, 116 . DOI: $10.3390 / \mathrm{md} 19020116$

[23] Chinglenthoiba, C., Das, A., Vandana, S. (2020). Enhanced biodiesel production from waste cooking palm oil, with $\mathrm{NaOH}$-loaded Calcined fish bones as the catalyst. Environ. Sci. Pollut. Res., 27(13), 15925-15930. DOI: 10.1007/s11356-020-08249-7

[24] Manaf, I.S.A., Yi, C.J., Ab. Rahim, M.H., Maniam, G.P. (2019). Utilization of waste fish bone as catalyst in transesterification of RBD palm oil. Mater. Today: Proceedings, 19, 1294-1302. DOI: 10.1016/j.matpr.2019.11.140 
[25] Jeremiah, P.A., Jalil, A.A., Olutoye, M.A. (2019). Heterogeneous catalyst application in biodiesel production: Needs to focus on cost effective and reusable catalysts. IOP Conf. Series: Mater. Sci. Eng., 808, 012013. DOI: 10.1088/1757-899X/808/1/012013

[26] Chakraborty, R., RoyChowdhury, D. (2013). Fish bone derived natural hydroxyapatitesupported copper acid catalyst: Taguchi optimization of semibatch oleic acid esterification. Chem. Eng. J., 215-216, 491-499. DOI: 10.1016/j.cej.2012.11.064.

[27] Patel, S., Han, J., Qiu, W., Gao, W. (2015). Synthesis and characterisation of mesoporous bone char obtained by pyrolysis of animal bones, for environmental application. J. Environ. Chem. Eng., 3, 2368-2377. DOI: 10.1016/j.jece.2015.07.031.

[28] Yin, T., Park, J.W., Xiong, S. (2015). Physicochemical properties of nano fish bone prepared by wet media milling LWT - Food Sci. Technol., 64(1), 367-373. DOI: 10.1016/j.lwt.2015.06.007

[29] Zayed, E.M., Sokker, H.H., Albishri, H.M., Farag, A.M. (2013). Potential use of novel modified fishbone for anchoring hazardous metal ions from their solutions. Ecol. Eng., $61, \quad 3900-393 . \quad$ D O I : 10.1016/j.ecoleng.2013.09.010

[30] Szpak, P. (2011). Fish bone chemistry and ultrastructure: implications for taphonomy and stable isotope analysis. J. Archaeol. Sci., $38(12), \quad 3358-3372$. D O I : 10.1016/j.jas.2011.07.022

[31] Boutinguiza, M., Poua, J., Comesaña, R., Lusquiños, F., Carlos, A.d., Leóna, B. (2012). Biological hydroxyapatite obtained from fish bones. Mater. Sci. Eng.: C, 32(3), 478-486. DOI: 10.1016/j.msec.2011.11.021

[32] Poh, N.E., Nur, H., Muhid, M.N.M., Hamdan, H. (2006). Sulphated AlMCM-41: Mesoporous solid Brønsted acid catalyst for dibenzoylation of biphenyl. Catal. Today, 114(2-3), 257-262. DOI: $10.1016 /$ j.cattod.2006.01.010

[33] Peng, L., Philippaerts, A., Ke, X., Van Noyen, J., De Clippel, F., Van Tendeloo, G., Jacobs, P.A., Sels, B.F. (2010). Preparation of sulfonated ordered mesoporous carbon and its use for the esterification of fatty acids. Catal. Today, 50(1-2), 140-146. DOI: 10.1016/j.cattod.2009.07.066

[34] Duprey, E., Beaunier, P., Springuel-Huet, M.A., Bozon-Verduraz, F., Fraissard, J., Manoli, J.M., Brégeault, J.M. (1997). Characterization of Catalysts Based on Titanium Silicalite, TS-1, by Physicochemical Techniques. J. Catal., 165(1), 22-32. DOI: 10.1006/jcat.1997.1462.
[35] Liu, C., Huang, J., Sun, D., Zhou, Y., Jing, X., Du, M., Wang, H., Li, Q. (2013). Anatase type extra-framework titanium in TS-1: A vital factor influencing the catalytic activity toward styrene epoxidation. Appl. Catal., AGen, $459, \quad 1-7 . \quad$ D O I : 10.1016/j.apcata.2013.03.013

[36] Nur, H. (2006). Modification of titanium surface species of titania by attachment of silica nanoparticles. Mater. Sci Eng. B, 133, 49-54. DOI: $10.1016 /$ j.mseb.2006.05.003

[37] Tryba, B., Morawski, A.W., Inagaki, M. (2003). Application of TiO2-mounted activated carbon to the removal of phenol from water. Appl. Catal. B: Environ., 41, 427-433. DOI: 10.1016/S0926-3373(02)00173-X

[38] Padikkaparambil, S., Narayanan, B., Yaakob, Z., Viswanathan, S., Tasirin, S.M. (2013). Au/TiO2 Reusable Photocatalysts for Dye Degradation. Int. J. Photoenergy, 2013, 1-10. DOI: $10.1155 / 2013 / 752605$

[39] Tang, B., Lu, X.-H., Zhou, D., Lei, J., Niu, Z.H., Fan, J., Xia, Q-H. (2012). Highly efficient epoxidation of styrene and a-pinene with air over $\mathrm{Co}^{2+}$-exchanged ZSM-5 and Beta zeolites. Catal. Commun., 21, 68-71. DOI: 10.1016/j.catcom.2012.01.029

[40] Pei, J., Han, X., Lu, Y. (2015). Performance and kinetics of catalytic oxidation of formaldehyde over copper manganese oxide catalyst. Build. Environ., 84, 134-141. DOI: 10.1016/j.buildenv.2014.11.002

[41] Tseng, T.K., Chu, H. (2001). The kinetics of catalytic incineration of styrene over a $\mathrm{MnO} / \mathrm{Fe}_{2} \mathrm{O}_{3}$ catalyst. Sci. Total Environ., 275(1-3), 83-93. DOI: 10.1016/s00489697(00)00856-1

[42] Laidler, K.J. (1988). Chemical Kinetics. Second Edition. New Delhi: Tata McGraw-Hill Publishing Company Ltd.

[43] Alimardanov, H.M., Veliyeva, F.M., Garibov, N.I., Musayeva, E.S. (2020). Kinetic relationships of liquid-phase oxidation of styrene with hydrogen peroxide in the presence of polyoxotungstate modified with cerium cations. Russian J. Appl. Chem., 93, 729-740. DOI: $10.1134 / \mathrm{S} 1070427220050146$ 